\author{
A. Kushneruk, \\ Postgraduate student of State educational and scientific establishment \\ "The Academy of Financial Management" \\ ORCID ID: 0000-0002-0691-2268 \\ N. Alekseienko, \\ Postgraduate student of State educational and scientific establishment \\ "The Academy of Financial Management" \\ ORCID ID: 0000-0002-6497-6526
}

\title{
AGREEMENT OF THE ECONOMIC INTERESTS OF THE STATE AND THE PRIVATE CAPITAL IN PUBLIC-PRIVATE PARTNERSHIP PROJECTS
}

\author{
О. Й. Кушнерук, \\ аспірант, Державна навчально-наукова установа "Академія фінансового управління" \\ Н. М. Алексеєнко, \\ аспірант, Аержавна навчально-наукова установа "Академія фінансового управління"
}

\author{
УЗГОАЖЕННЯ ЕКОНОМІЧНИХ ІНТЕРЕСІВ АЕРЖАВИ ТА ПРИВАТНОГО КАПІТААУ \\ В ПРОЕКТАХ АЕРЖАВНО-ПРИВАТНОГО ПАРТНЕРСТВА
}

The economic development of any statedepends on its effective interaction with economic entities. In Ukraine, this issue is quite complicated, as legislation that regulates business activity is constantly changing. For this reason, most of the business is in the shadows, which is why the state does not receive significant funds for their budgeting. Therefore, thanks to the effective cooperation of all economic entities, each party receives its benefits - the business has clear and transparent rules of the game, and the state receives a corresponding filling of the budget, which in turn leads to timely payments of various social obligations and other expenses. Thus, in this article the issue of the very problems of interaction between the state and the private capital is covered, the theoretical substantiation of the importance of effective reconciliation of economic interests of the state and private sectors of the national economy is considered, the relevance of public-private partnership is shown on the example of other countries. The essence and peculiarities of the concept of "reconciliation of economic interests", various options of cooperation between the state and business, their results and consequences are considered. The essence of public-private partnership and its advantages are explained. The solutions that are needed for a more efficient and effective launch of public-private partnership in Ukraine with the attraction of private investment and modernization of the country and its economic growth are proposed.

The relevancy of this issue is determined by the search for directions for ensuring the current efficiency of the national economy and improving the economic system as a whole, which requires the development of scientific and practical recommendations on the convergence of interests of the state and the private sector in the current conditions.

The purpose of the article is to theoretically substantiate the importance of effectively reconciling the economic interests of the public and private sectors of the national economy through public-private partnerships. 


\section{ЕКОНОМІЧНА НАУКА}

Устатті встановлено, що економічний розвиток будь-якоїдержави залежить від ефективності ї̈ взаємодї з Суб'єктами Господарювання в цілому та сектору нефінансових і фінансових корпорацій, особливої гостроти дане питання набирає в проектах, державно-приватного партнерства, які на національному рівні визначено домінантою структурного реформування національної економіки. Розглянуто сутнісноеволюційну скАадову поняття "Узгодження економічних інтересів", типологізовані інваріацію механізмів Узгодження економічних інтересів держави та корпорацій, їх результати і наслідки дАя національної економічної системи. Типологізовано та запропоновано принципи кАастеризації узгоження економічних інтересів загалом та проектах, державно-приватного партнерства зокрема. Здійснено їх проекцію на теорію контрактів (Олівера Харта і Бенгта Хольмстрьома), яка в 2016 р. отримала Нобелівську премію 3 економіки, дозволяючи подивитися під новим методологічним кутом на проблеми балансування економічних інтересів держави, сектору нефінансових і фінансових корпорацій та інших Стейкхолдерів. Досліджено інституційне і регуляторне середовище функціонування проектів державно-приватного партнерства та балансування економічних інтересів з проекцією на фіскальний потенціал бюджетів різних рівнів, зокрема в умовах пануючої реформи місцевого самоврядування і бюджетної,децентралізації. 3 Урахуванням існуючої імперики встановлені взаємовпливи та взаємозв 'язки економічних інтересів держави і приватного капіталу (сектору нефінансових і фінансових корпорацій) в проектах,державно-приватного Партнерства, запропоновані тактичні заходи дАя підвищення результативності процесу Узгодження економічних інтересів держави і приватного капіталу в інвестиційних проектах, зокрема ті, що реалізуються в рамках механізмів державно-приватного партнерства. Наведені конкретні та вагомі реГуляторно-інституційні поступи Створення єАиного конкурентного середовища дАя СУб'єктів інституційних секторів економіки України в рамках реформи державних закупівель (їх обсят щорокускАадає близько 13 \% ВВП України), зокрема через доступ,до електронної системи "ProZorтo".

Keywords: economic entity, state, private capital, reconciliation of economic interests, public-private partnership.

Ключові слова: суб'єкт господарювання, держава, інвестичійний проект, приватний капітал, узгодження економічних інтересів, державно-приватне партнерство, секторнефінансових і фінансових корпорачій.

\section{STATEMENT OF THE PROBLEM AND ITS RELEVANCE}

An important condition for the development of any society is the need to reconcile its economic interests. In Ukraine, this topic is poorly researched and studied unlike other successful countries. Therefore, the reconciliation of the economic interests of the state and private capital is of utmost importance. The state should give everyone equal access to material goods, but in practice this is not the case. Although today, this situation has started to change for the better, as an example - the business has access to the electronic system "Prozorro" (that means - Transperent), a Public Procurement System ("Prozorro") emerged during the implementation of the Public Procurement Reform, which in turn provides equal opportunities for fair competition of business entities. But there are also a number of unspoken agreements between participants in public procurement, which often leads to unlawful results of public competition. Due to the fact that this state of affairs poses a threat to the security of the state not only as a political organization of society, but also as a "perfect and selfsufficient existence", the reconciliation of the economic interests of the state and private capital through publicprivate partnership is one of the topical tasks facing the domestic school of theoretical economics today.

The urgency of this issue is determined by the search for directions for ensuring the current efficiency of the national economy and improving the economic system as a whole, which requires the development of scientific and practical recommendations on the convergence of interests of the state and the private sector in the current conditions.

\section{ANALYSIS OF RECENT RESEARCH} AND PUBLICATIONS

Problems of interaction between the state and the private sector in the process of realization of economic interests, were investigated in the works of such foreign scientists as Roderick M. Kramer and Todd L. Pittinsky [1], Richard M. Buxbaum, Allen Hirsch, Klaus J. Hopt [2], Fernando Gomez and Jose Juan [3] and others.

In the Ukrainian economic science the works of O.O. Belopolskaya and S.M. Frolov [4]. Are devoted to the problems of the interaction between the state and business through private-public partnership in the sphere of investment.

J. Lisun [5] deals with the research: the formation of the public-private partnership mechanism as a tool for stabilization and development of the Ukrainian economy.

The works of such scientists as T.I. Efimenko, E.L. Cherevikov, K.V. Pavlyuk [6] are dedicated to the research of public-private partnership in the system of the economy regulation and others [16-20].

There are no complete studies of the peculiarities of influence of the corporate sector on the economic interests of economic entities today, at the stage of development of economic systems due to the fact that it is difficult to apply foreign experience of other countries because of the specific nature of the Ukrainian economy. This determines the choice of this article's topic and its purpose.

\section{FORMULATING OF THE ARTICLE'S GOALS}

The purpose of the article is to substantiate theoretically the importance of effectively reconciling the economic interests of the public and private sectors of the national economy through public-private partnerships.

\section{PRESENTING MAIN MATERIAL}

At the present stage of economic relations development, Ukraine does not possess sufficient characteristics of a special economic entity, but instead acts as a formal owner and expresser of interests of all population groups. At the same time, it actually realizes the owner's powers for a relatively large part of the property through the regulation of energy and fuel tariffs, the differentiated use of bankruptcy procedures for working and unprofitable 
enterprises, the election of laws that prevent the effective operation of certain entities and the granting of preferences to others etc. Often the state and business are in opposition, in constant confrontation with each other. And the state does not act as an auxiliary body but as a punitive one, which is very negatively perceived by business and society as a whole.

The system of interconnected and interacting interests of society is always contradictory. Therefore, every society faces the challenge of finding an effective mechanism for their harmonization. The unity of interests is achieved in the process of their interaction and mutual realization.

The economic interests of entrepreneurs are aimed at maximizing profits, reducing costs and improving the competitiveness of products, economic interests of the state aimed at meeting the needs of society as a whole.

Considering that the interests of the state and business do not always coincide, the concept of "reconciliation of economic interests of the state and private capital" in economic science has not yet been sufficiently developed, but several general interpretations of the harmonization of economic interests are available. By using the method of critical analysis, the most effective provisions for a solvable task are identified, some of which interpret the reconciliation of economic interests as:

a) subordination of one economic interest to another ones [7];

b) the principle of making economic decisions, in accordance with which constant interaction and cooperation between government representatives and economic entities are carried out to ensure comparability of management economic information of different levels, consistency, coherence of jointly made decisions [8, p. 57].

Reconciling the economic interests of the state and private capital involves state's managing the economic behavior of the owners of the means of production through their economic interest by creating conditions that motivate them to make such economic decisions that would give their interests the "driving" force of socio-economic development and thus serve to realize economic interest of the state as an expresser of the general interest.

From this we can deduce the essence of reconciling economic interests:

a) the state produces public goods and services necessary for the realization of the economic interest of private capital, which capital alone cannot create in the full necessary amount alone;

b) private capital creates modern working conditions, organizes efficient production of goods and services receives income and pays taxes from them, which are the main source of state budget revenues (the material form of expression of the economic interest of the state).

In such a way we see a pretty serious problem of economic relations between the state and private capital. In our days, both: the state and private business are not being as partners in the economic activity. This issue abroad is resolved through state-business interaction which is called: "Public-Private Partnership".

This form of interaction will allow the cooperation between the state and the private sector to get out of the economic deadlock. For business - the state should become a partner, not a punitive body, how it is being perceived by the majority of Ukrainian society. Therefore the state has undertaken a number of commitments, including "accelerating progressive structural and institutional changes in the economy, improving the investment climate, improving the efficiency of investment processes; stimulation of advance development of high-tech industries" [9], which indicates the desire and willingness to cooperate effectively with business.

In Ukraine the relevant law on public-private partnership (PPP) was signed on July 1, 2010. In the US, a similar law was enacted in the 1950 -s, initially in connection with the co-financing of education programs by public and private sector.

In this country, the main advantage of public-private partnership development is that, as most contemporary economics researchers believe, that the US as a state has sufficient autonomy from the economy and civil society. It is worth noting the rule of law, which is quite well spelled out in Ukrainian legislation, but in practice everything looks very different, with strong bureaucratic and political involvement.

In the European Union, state-private partnership is considered as Public Private Partnership (PPP), which is defined as the "transfer to the private sector the part of authority, responsibilities and risks of implementing investment projects that have traditionally been implemented or funded by the public" or as "a system of relations between a public authority (management) and a private organization, in which the second one is receiving a greater role in the planning, financing and implementation of a specific service for the population, than during the use of traditional procedures of cooperation (such as a tender), and lower than in the mechanism of privatization. At the same time, the protection of state and communal interests is guaranteed through institutional bases, provisions of normative acts and signed agreements" [10].

In the Law of Ukraine "On Public-Private Partnership", this partnership is defined as a system of relations between public and private partners, built on the principles of equality of partners and reconciliation of their interests, in which the opportunities of both partners are combined, with appropriate sharing of the risk, responsibility and obtaining a positive end result for mutually beneficial long-term cooperation [11].

This law was amended in 2012, 2015, 2017, 2019, which in turn speaks of the insufficient level of legislative support of public-private partnership in Ukraine, as well as that in the process of cooperation with the private sector there is a real dialogue, which is reflected in the permanent edits and improvements of this law.

Public-private partnership is currently being used in the 22 countries of Europe and Eastern Asia, as well as in Canada, Australia, Japan, India, China, the United States and other developed countries.

In world practice, public-private partnership in the broad sense is "a system of relations between the state and business, which is widely used as a tool of national, international, regional, urban, municipal, economic and social development" $[12$, p. 12]. In the narrow sense, publicprivate partnerships are "the specific projects implemented jointly by public authorities and private companies on the state and municipal property" [12, p. 12].

One of the most important aspects of public-private partnerships is enabling the private sector to participate in infrastructure reconstruction and provision of public services. In such a way, more finances, experience and management skills are being attracted that are otherwise unavailable to the public sector.

The mechanism of cooperation between the public and private sectors is that a private company provides certain services to the community, using assets that are in the stateowned communal property [13].

This is a long-term partnership, although the private partner invests money and manages the project effectively, but it does not imply the transfer of property rights to the investor, that is, the investor acquires the rights of use for a long time, but after that time - everything becomes property of the community, and each party makes a profit while using the resources provided.

Public-private partnerships have become widespread in most countries of the world, where they see it as one of the main instruments for economic development. The partnership enables the state and the private sector to benefit from the pooling of financial, management and technological resources by combining the socially important 
tasks of the country's socio-economic development with the achievement of business and community interests [14].

But this practice is not sufficiently implemented yet in Ukraine and is in the early stages of its formation now.

Therefore, today there are many problems that hinder the development of public-private partnership in Ukraine, the main ones are [15]:

1) A lack of experienced staff that could develop publicprivate partnerships, both from the business and the state sides;

2) An absence of projects that are attractive and meet the requirements of the banks (bank blue projects);

3) A private sector unpreparedness: a small number of private operators in an extremely small number of sectors. The perception in the Ukrainian business environment of public-private partnerships and concessions as projects with extremely high risks, low profitability and uncertainty about future conditions;

4) Unpreparedness of the authorities for partnership and implementation of public-private partnership projects;

5) Gaps and limitations of legislation (including concession), lack of the enforcement practice law;

6) Insufficient regional activity in project initiation and implementation;

7) Unwillingness to invest in long-term projects, etc.

Despite the 186 contracts already implemented jointly with the state, since 2010 to present time, this is not sufficient to substantially affect the transformation of the country's economy. This demonstrates that the shadow economy, constant changes in the rules of the game in the market, not transparent legislation by the state does not facilitate such cooperation. Entrepreneurs by including scientists also, and working in tandem with the state, must solve these issues. The state is not a good manager in managing certain resources. In contrast, businesses have the experience and ability to successfully implement many projects.

Finally, it is worth noting the assistance of foreign partners in building public-private partnerships, in particular, there is a Public Private Partnership Development Program (PPDP) funded by the United States Agency for International Development (USAID).

\section{CONCLUSION}

Reconciling the economic interests of the state and private capital involves state's managing of the economic behavior of the production means' owners through their economic interest by creating conditions that motivate them to make such economic decisions that would give them the interests of the "driving" force for economic development and thus serve the realization of economic interest of the state as an expression of general interest.

The essence of economic interests reconciling is the following:

a) The state produces public goods and services necessary for the realization of the economic interest of private capital, which capital alone cannot create in the full amount necessary for it;

b) The private capital creates modern working conditions and organizes efficient production of goods and services - receives income and pays taxes from them, which are the main source of state budget revenues (material form of expression of the economic interest of the state).

The reconciliation of economic interests fully corresponds to the economic interests of both parties: the state and private capital.

Therefore, based on the fact that in most countries of the world public-private partnership is one of the main instruments of economic development, we conclude that public-private partnership is an effective mechanism for attracting investment resources in the economic transformation of the country. This pooling of financial, management and technological resources allows for maximum mutual benefit. The cooperation of the state with business in the near future will lead to more efficient use of resources and solving problems of socio-economic development. Developing appropriate mechanisms for statebusiness partnerships with foreign partners is one of the main common directions, which is more than ever relevant and urgent.

\section{$\Lambda$ ітература:}

1. Крамер Р.М., Піттінський Т.А. Відновлення довіри до організацій та лідерів: постійні виклики та нові відповіді. URL: https://www.oxfordscholarship.com/view/ 10.1093 / acprof:oso/9780199756087.001.0001/acprof9780199756087

2. European Business Law. Legal and Economic Analyses on Integration and Harmonization/ ed. by R.M. Buxbaum. Berlin, New York. 1991. 413 p.

3. Гомес Ф., Хуан Х. Економічний аналіз режимів гармонізації: повна гармонізація, мінімальна гармонізація чи додатковий інструмент? URL: https://www.researchgate.net/publication/228466831_An_Economic_Analysis_of_Harmonization_Regimes_Full_Harmonization_Minimum_Harmoñzation_or_Optional_Instrument

4. Білопільська О.О., Фролов С.М. Аержавно-приватне партнерство як механізм інвестування інноваційних технологій поводження з відходами. Бізнес Інформ. 2013. № 3. C. $181-185$.

5. Аісун Я. В. Формування механізму державно-приватного партнерства як інструменту стабілізації та розвитку економіки України. URL: http://jvestnikc.donnu.edu.ua/article/view/306/317

6. Аержавно-приватне партнерство в системі регулювання економіки: монографія / Єфименко Т.I., Черевиков Є. А., Павлюк К.В. та ін.; за заг. ред. чл.-кор. НАНУ T.I. Єфименко. Київ: НАН України, Ін-т екон. та прогнозув., 2012. С. 125-126.

7. Економічні інтереси, їхня класифікація та взаємодія. URL: https://pidruchniki.com/1281041939912/ politekonomiya/ekonomichni_interesi_yihnya_klasifikatsiya_vzayemodiya

8. Богдан Н.М. Концептуальні підходи до формування механізму узгодження економічних інтересів суб'єктів на регіональному рівні. Бізнес Інформ. 2018. № 4. C. 55-61.

9. Про основи національної безпеки України: закон України від 21.08.2018 № 2649-VIII. URL: https://zakon.rada.gov.ua/laws/show/964-15

10. Аанилишин Б. М. Аналіз регуляторного впливу при впровадженні Закону України "Про загальні засади розвитку державно-приватного партнерства в Укpaïнi". URL: http://www.me.gov.ua/ control/uk/publish/ article/system

11. Про державно-приватне партнерство: закон УКраїни від 01.08.2010 № 2404-VI. URL: https://zakon.rada.gov.ua/laws/show/2404-17

12. Варнавский В.Г., Клименко А.В., Королев В.А. и др. Государственно-частное партнерство: теория и практика: учеб. пособие. Москва: Высш. шк. экономики, 2010. 287 с.

13. Що таке державно-приватне партнерство? URL: https://www.sfii.gov.ua/що-таке-державно-приватнепартнерств

14. Про затвердження середньострокового плану пріоритетних дій Урядуда 2020 року та плану пріоритетних дій Уряду на 2017 рік: розпорядження Кабінету Міністрів України від 03.04.2017 № 275-p. URL: https:// zakon.rada.gov.ua/laws/show/275-2017-p

15. Павлова Г.О. Аержавно-приватне партнерство: аналіз світового досвіду та шляхи розвитку в Україні. URL: http://www.kbuapa.kharkov.ua/ e-book/putp/20113/doc/3/02.pdf

16. Petrukha N.M., Petrukha S.V. Efficiency evaluation of investment innovative projects based on public-private partnership in the agrarian sector of Ukrainian economy. Актуальні проблеми економіки. 2015. № 9. С. 141-148. 
17. Котляревський Я.В., Петруха С.В. Управління мобілізацією фінансових ресурсів державними корпораціями. Актуальні проблеми розвитку системи управління державними фінансами: євроінтеграційний контекст: монографія / За ред. Т.І. Єфименко; АННУ "Акад. фін. управління". Київ, 2016. С. 227-242.

18. Гасанов С., Петруха С. Зарубіжний досвід державно-приватного партнерства в агрострахуванні. Економіст. 2014. № 8. С. 17-22.

19. Гасанов С., Петруха С., Петруха Н. Онтогенез теоретичних концепцій інтеграції. Економіст. 2015. № 1 . С. $15-21$.

20. Забловський А., Петруха С., Назукова Н. Генезис та еволюція податкової детермінанти в типологізованих моделях інвестиційної поведінки. Black Sea Scientific Journal of Academic Research. 2015. № 5 (23). C. $20-25$.

\section{References:}

1. Kramer, R.M. and Pittins'kyj, T.L. (2012), "Restoring trust in organizations and leaders: ongoing challenges and new responses", available at: https:/ www.oxfordscholarship.com/view/10.1093/acprof:oso/9780199756087.001.0001/acprof-9780199756087 (Accessed 10 April 2020).

2. Buxbaum, R.M. (1991), European Business Law. Legal and Economic Analyses on Integration and Harmonization, New York, USA.

3. Homes, F. and Khuan, Kh. (2011), "Economic analysis of harmonization regimes: full harmonization, minimal harmonization or additional tool?", available at: https:// www.researchgate.net/publication/228466831 An Economic_Analysis_of_Harmonization_Regimes_Full Harmonization Minimum Harmonization or OptionalInstrument (Accessed 10 Āpril 2020).

4. Bilopil's'ka, O.O. and Frolov, S.M. (2013), "Publicprivate partnership as a mechanism for investing in innovative waste management technologies", Biznes Inform, vol. 3 , pp. $181-185$.

5. Lisun, Ya.V. (2015), "Formation of the mechanism of public-private partnership as a tool for stabilization and development of Ukraine's economy", Visnyk Donets'koho natsional'noho universytetu. Seriia V. Ekonomika i pravo, available at: http://jvestnik-c.donnu.edu.ua/article/view/ 306/317 (Accessed 10 April 2020).

6. Yefymenko, T.I. Cherevykov, Ye.L. and Pavliuk, K.V. (2012), Derzhavno-pryvatne partnerstvo v systemi rehuliuvannia ekonomiky [Public-private partnership in the system of economic regulation], NAN Ukrainy, In-t ekon. ta prohnozuv., Kyiv, Ukraine, pp. 125-126.

7. Bazylevych, V.D. (2007), "Economic interests, their classification and interaction", available at: https://pidruchniki.com/1281041939912/politekonomiya/ekonomichni interesi yihnya_klasifikatsiya_vzayemodiya (Accessed 10 April 2020).

8. Bohdan, N.M. (2018), "Conceptual approaches to the formation of a mechanism for reconciling the economic interests of entities at the regional level", Biznes Inform, vol. 4 , pp. 55-61.

9. Verkhovna Rada of Ukraine (2003), The Law of Ukraine "On the foundations of national security of Ukraine", available at: https://zakon.rada.gov.ua/laws/ show/964-15 (Accessed 10 April 2020).

10. Danylyshyn, B.M. (2009), "Analysis of regulatory impact in the implementation of the Law of Ukraine "On General Principles of Public-Private Partnership Development in Ukraine", available at: http://www.me.gov.ua/ control/uk/publish/article/system (Accessed 10 April 2020).

11. Verkhovna Rada of Ukraine (2010), The Law of Ukraine "About public-private partnership", available at: https://zakon.rada.gov.ua/laws/show/2404-17 (Accessed 10 April 2020).

12. Varnavskyj, V.H. Klymenko, A.V. and Korolev, V.A. (2010), Hosudarstvenno-chastnoe partnerstvo: teoryia y praktyka [Public-private partnership: theory and practice], Vyssh.shk. ekonomyky, Moscow, Russia.

13. SFII (2020), "What is a public-private partnership?", available at: https://www.sfii.gov.ua/scho-take-derzhavnopryvatne-partnerstv (Accessed 10 April 2020).

14. Cabinet of Ministers of Ukraine (2017), Resolution "On approval of the medium-term plan of priority actions of the Government until 2020 and the plan of priority actions of the Government for 2017", available at: https:// zakon.rada.gov.ua/laws/show/275-2017-r (Accessed 10 April 2020).

15. Pavlova, H.O. (2011), "Public-private partnership: analysis of world experience and ways of development in Ukraine", available at: http://www.kbuapa.kharkov.ua/ebook/putp/2011-3/doc/3/02.pdf (Accessed 10 April 2020).

16. Petrukha, N.M. and Petrukha, S.V. (2015), "Efficiency evaluation of investment innovative projects based on public-private partnership in the agrarian sector of Ukrainian economy", Aktual'ni problemy ekonomiky, vol. 9, pp. 141-148.

17. Kotliarevs'kyj, Ya.V. and Petrukha, S.V. (2016), "Management of mobilization of financial resources by state corporations" Aktual'ni problemy rozvytku systemy upravlinnia derzhavnymy finansamy: ievrointehratsijnyj kontekst [Current problems of public finance management system development: European integration context],DNNU "Akad. fin. upravlinnia", Kyiv, Ukraine, pp. 227-242.

18. Hasanov, S. and Petrukha, S. (2014), "Foreign experience of public-private partnership in agricultural insurance", Ekonomist, vol. 8, pp. 17-22.

19. Hasanov, S. Petrukha, S. and Petrukha, N. (2015), "Ontogenesis of theoretical concepts of integration", Ekonomist, vol. 1, pp. 15-21.

20. Zablovs'kyj, A. Petrukha, S. and Nazukova, N. (2015), "Genesis and evolution of the tax determinant in typological models of investment behavior", Black Sea Scientific Journal of Academic Research, vol. 5 (23), pp. 20 25 .

Стаття надійшла до редакиії 08.04.2020 р.

\section{www. dy.nayka.com.ua}

Електронне фахове видання

\section{ДЕРЖАВНЕШ УПРАВЛНННЯ удосконалення та розвиток}

\section{Виходить 12 разів на рік}

включено до переліку наукових фахових видань України 3 ПИтань ДЕРЖАВНОГО УПРАВЛІННЯ

(Категорія «Б»)

Наказ Міністерства освіти і науки України від 28.12.2019 №1643

e-mail:economy_2008@ukr.net

тел.: (044) 223-26-28

(044) $458-10-73$ 